\title{
Association between filaggrin family member genes, asthma, atopy and atopic asthma with atopic dermatitis history in the subjects from the Saguenay-Lac-Saint-Jean founder population
}

\author{
Marie-Hélène Lambert ${ }^{1,2^{*}}$, Karine Tremblay ${ }^{3}$, Anne-Marie Madore ${ }^{1,2}$, Catherine Laprise ${ }^{1}$ \\ From AllerGen NCE Inc.'s Fifth Annual Research Conference: Innovation from Cell to Society \\ Québec City, QC, Canada. 7-9 February 2010
}

\section{Objective/purpose}

To perform an association study between the filaggrin $(F L G)$ and the filaggrin family member 2 (FLG2) tagging single nucleotide polymorphisms (tagSNPs) and asthma, atopy, atopic asthma, as well as these affections in the presence of atopic dermatitis (AD).

\section{Methods}

Five tagSNPs covering FLG have been genotyped in 237 trios from the Saguenay-Lac-Saint-Jean population using a Sequenom panel. In addition, a genome-wide association study (GWAS) has also been done for the same trios in the large-scale GABRIEL project http://www. gabriel-fp6.org/. The polymorphisms (SNPs) included in FLG and FLG2 as well as those in the 3' and 5' UTR regions were extracted. Six SNPs were extracted for FLG (for a total of 11 SNPs when including the Sequenom panel) and 2 SNPs for FLG2. The association study for all the affections was done using a family-based association test (FBAT). The results were corrected using the Li and Ji method [1].

\section{Findings}

Positive associations were found between a haplotype block formed by FLG rs2184951 and rs12730241 (H1) and asthma and related phenotypes (see results in Table 1).

Table 1 Association of FLG haplotype and tagSNPs with asthma and atopy (A) and with asthma and atopy that cooccur with the presence of a personal history of atopic dermatitis (B)

\begin{tabular}{|c|c|c|c|c|c|c|c|c|c|c|}
\hline \multicolumn{11}{|l|}{$\bar{A}$} \\
\hline \multirow[t]{2}{*}{ SNP } & \multirow[t]{2}{*}{ Allele } & \multicolumn{3}{|l|}{ Asthma } & \multicolumn{3}{|l|}{ Atopy } & \multicolumn{3}{|c|}{ Atopic asthma } \\
\hline & & $\mathrm{S}: \mathrm{E}(\mathrm{S})$ & $\mathbf{Z}$ & $p$ & $\mathrm{~S}: \mathrm{E}(\mathrm{S})$ & $\mathrm{Z}$ & $p$ & $\mathrm{~S}: \mathrm{E}(\mathrm{S})$ & $\mathbf{Z}$ & $p$ \\
\hline \multirow[t]{2}{*}{ rs3126085 } & $A$ & $32.0: 50.2$ & -3.48 & 0.0005 & $35.0: 49.8$ & -2.94 & 0.0033 & $25.0: 37.2$ & -2.74 & 0.0061 \\
\hline & G & 148.0:129.8 & 3.48 & & 141.0:126.2 & 2.94 & & 109.0:96.8 & 2.74 & \\
\hline \multicolumn{11}{|l|}{$\bar{B}$} \\
\hline \multirow[t]{2}{*}{ SNP/Haplotype } & Allele & \multicolumn{3}{|c|}{ Asthma and $A D$} & \multicolumn{3}{|c|}{ Atopy and AD } & \multicolumn{3}{|c|}{ Atopic asthma and AD } \\
\hline & & $S: E(S)$ & $\mathbf{Z}$ & $\mathbf{p}$ & $\mathrm{S}: \mathrm{E}(\mathrm{S})$ & Z & $\mathbf{P}$ & $\mathrm{S}: \mathrm{E}(\mathrm{S})$ & $\mathbf{Z}$ & $p$ \\
\hline \multirow[t]{2}{*}{ rs3126085 } & $A$ & $14.0: 24.0$ & -2.94 & 0.0033 & $16.0: 24.5$ & -2.59 & 0.0097 & 10.0:18.0 & -2.74 & 0.0062 \\
\hline & G & $66.0: 56.0$ & 2.94 & & $62.0: 53.5$ & 2.59 & & $52.0: 44.0$ & 2.74 & \\
\hline $\mathrm{H} 1$ & $T G$ & $75.0: 66.0$ & 2.61 & 0.009 & $75.0: 64.0$ & 3.33 & 0.0009 & $60.0: 51.0$ & 2.94 & 0.0033 \\
\hline
\end{tabular}

'Université du Québec à Chicoutimi, Chicoutimi, Canada, G7 H 2B1

Full list of author information is available at the end of the article 


\section{Deliverables}

To conclude, FLG and FLG2 are genes associated with asthma. Functional studies will be necessary to document the molecular structure (sequence) and role of these genes in asthma and the impact of the genetic variants.

\section{Relevance}

Identification of associated genes is fundamental to document the molecular nature of asthma in order to increase knowledge of the pathophysiology of this complex trait.

\section{Author details}

'Université du Québec à Chicoutimi, Chicoutimi, Canada, G7 H 2 B1.

Université Laval, Québec, Canada, G1V 0A6. ${ }^{3}$ Université de Montréal,

Montréal, Canada, H3C 3J7.

Published: 26 November 2010

\section{Reference}

1. Li J, Ji L: Adjusting multiple testing in multilocus analyses using the eigenvalues of a correlation matrix. Heredity 2005, 95:221-227.

doi:10.1186/1710-1492-6-S3-P4

Cite this article as: Lambert et al:: Association between filaggrin family member genes, asthma, atopy and atopic asthma with atopic dermatitis history in the subjects from the Saguenay-Lac-Saint-Jean founder population. Allergy, Asthma \& Clinical Immunology 2010 6(Suppl 3):P4.

Submit your next manuscript to BioMed Central and take full advantage of:

- Convenient online submission

- Thorough peer review

- No space constraints or color figure charges

- Immediate publication on acceptance

- Inclusion in PubMed, CAS, Scopus and Google Scholar

- Research which is freely available for redistribution

Submit your manuscript at www.biomedcentral.com/submit 